\title{
A inteoração latino-americana no pensamento de Aldo ferrer
}

Heloisa Jochims Reichel*

Resumo: $\mathrm{O}$ artigo analisa o tema da integração econômica, mais especificamente o da formação de blocos comerciais na América Latina, associado à trajetória de um intelectual - a do argentino Aldo Ferrer -, que, tendo iniciado suas atividades de economista e sua produção intelectual nos anos cinquenta, período em que era frequente o engajamento dos intelectuais na política, permanece em atividade até os dias de hoje, quando encontramos o silêncio predominando dentre a categoria. $\mathrm{O}$ objetivo consiste em acompanhar a atuação do referido intelectual no que diz respeito ao tema indicado, desde o surgimento, em 1960, do primeiro bloco econômico regional que integrava países da América Latina - Associação Latino-Americana de Livre Comércio (ALALC) - até os dias recentes, em que se destaca a formação do Mercado Comum do Sul - Mercosul. Na análise, busca-se identificar permanências e mudanças que possam ter ocorrido no pensamento e na forma de atuação do intelectual, considerando, também, as diferentes conjunturas e ordens mundiais por ele vivenciadas.

Palavras-Chave: Intelectuais. Aldo Ferrer. Integração. América Latina. Argentina.

Tem sido frequente a utilização do termo "silêncio" para caracterizar a forma como os intelectuais vêm participando na sociedade atual. Adauto Novaes, organizador da obra O Silêncio

\footnotetext{
* Professora de graduação e do Programa de Pós-Graduação em História na Universidade do Vale do Rio dos Sinos. E-mail: hreichel@unisinos.br.
}

Anos 90, Porto Alegre, v. 16, n. 29, p.183-212, jul. 2009 
A integração latino-americana no pensamento de Aldo Ferrer...

dos Intelectuais (2006, p.7-18), considera que o uso dessa palavra expressa a crise que a categoria vivencia nas últimas duas décadas. Segundo ele, incapaz de interpretar o processo de mutação por que passa a civilização ocidental, em que o passado parece inexistir, o presente é fugaz e o futuro mostra-se incerto e impossível de imaginar, o intelectual tem preferido não intervir na prática política. $\mathrm{Na}$ maioria das vezes, tem-se confinado em gabinetes e desenvolvido atividades acadêmicas e de pesquisa em universidades, pouco se comunicando com o público em geral. Quando a comunicação acontece, frequentemente, torna-se refém dos interesses e da lógica imediatista e volátil da mídia.

Contudo, não foi sempre essa a forma de atuação dos intelectuais. Até os anos oitenta do século passado, quando ainda vigorava a Guerra Fria, era comum a atitude engajada com que eles intervinham na esfera pública, postulando, muitas vezes, a transgressão da ordem estabelecida e fazendo a crítica da existente.

Durante todo o período em que capitalismo e socialismo disputaram a hegemonia mundial, os intelectuais da América Latina foram chamados a se posicionar. A partir dos anos cinquenta, devido a fatores como o surgimento da Comissão Econômica para a América Latina (Cepal) e o desenvolvimento das ciências sociais nos países da região, houve um aumento crescente do grupo de intelectuais que defendia uma política externa soberana e anti-imperialista, opondo-se radicalmente às propostas de união continental sugeridas pelos Estados Unidos, bem como a adoção de uma postura claramente favorável à dimensão latino-americana no que tange aos assuntos relativos ao desenvolvimento econômico e à integração.

Até o momento em que eclodiu a revolução em Cuba, ainda existia um certo equilíbrio de forças entre os que se manifestavam pró-EUA e os que se mostravam resistentes aos norte-americanos e simpáticos ao socialismo. Após aquele movimento, porém, cresceu a influência das ideias originadas no pensamento de Marx entre os intelectuais e o segundo grupo, denominado genericamente 
de intelectuais de esquerda ou progressistas ${ }^{1}$, passou a predominar dentre a categoria.

Ao longo das décadas de sessenta e setenta do século passado, a prosperidade e a estabilidade dos países ricos, confrontadas com a pobreza e a instabilidade política que se faziam presentes nos países menos desenvolvidos, reforçaram a discussão dos problemas que afetavam a América Latina. Naquele momento, intelectuais de uma ou de outra posição acreditaram que deveriam atuar junto às agendas políticas que buscavam a transformação da realidade latino-americana, pleiteando e/ou oferecendo políticas de ação que revertessem essa situação. Halperin Donghi (1987) assim se referiu quanto a isso:

(...) Esa década incluye la definición socialista de la revolución cubana, pero también la muerte del Che, y su legado más importante para Latinoamérica continental va a ser la invención de um nuevo estilo de autoritarismo militar, surgido por primera vez em Brasil a partir de 1964. Em medio de las peripécias de esos años trágicos, ni científicos sociales ni escritores hallan fácil establecer una relación sin ambiguidades entre su obra especifica y su condición de participantes - que casi nunca se resignan a ser sólo participantes- en esa marcha de rumbo cada vez. más incierto (HALPERIN DONGHI, 1987, p. 281).

Aproveitando-se do reconhecimento que a sociedade lhes conferia, os intelectuais atuavam engajados na vida social e política do continente. Para que isso acontecesse, afora o status de saber privilegiado atribuído às ciências sociais, muito contribuiu a influência que a concepção de intelectual formulada por Antonio Gramsci exercia na categoria. Na obra Os intelectuais e a organização da cultura, Gramsci (1981) destacara que cada grupo social cria para si, de um modo orgânico, uma ou mais camadas de intelectuais, os quais se tornarão responsáveis pela elaboração de uma teoria que permitirá uma relativa homogeneidade entre a classe, tanto na esfera 
A integração latino-americana no pensamento de Aldo Ferrer...

econômica, quanto na política ou na social. Dessa forma, os intelectuais orgânicos possuem a eminente função de conscientizar as camadas populares da sociedade no sentido destas, alienadas pelo sistema capitalista, tornarem-se capazes de discernir sua função prática na produção da sua responsabilidade como cidadão e como ator social. ${ }^{2}$

Sob essa concepção, ou seja, na tentativa de atuarem como consciência da sociedade e de possibilitarem a concretização de transformações que julgavam necessárias, os intelectuais latinoamericanos ocuparam cargos nos governos de seus países e em organismos internacionais, assim como buscaram canais de comunicação que lhes permitissem o diálogo com a sociedade e com seus pares, tais como a publicação de obras ou de artigos em revistas especializadas e em jornais.

Para o presente texto, optamos por analisar como tema a integração econômica, mais especificamente a formação de blocos comerciais na América Latina, associando a isso a trajetória do argentino Aldo Ferrer, um intelectual que, tendo iniciado suas atividades de economista e sua produção intelectual nos anos cinquenta, período em que era frequente o engajamento dos intelectuais na política, permanece em atividade até os dias de hoje, quando encontramos o silêncio predominando dentre a categoria. Nosso objetivo consiste em acompanhar a atuação e a produção do referido intelectual no que diz respeito ao tema indicado, desde o surgimento, em 1960, do primeiro bloco econômico regional que integrava países da América Latina - Associação Latino-Americana de Livre Comércio (ALALC) - até os dias recentes, em que se destaca a formação do Mercado Comum do Sul - Mercosul. Na análise, buscamos identificar permanências e mudanças que possam ter ocorrido no pensamento e na forma de atuação de Aldo Ferrer, considerando, também, as diferentes conjunturas e ordens mundiais por ele vivenciadas.

O artigo se insere no campo de estudos da história intelectual, a qual vem registrando uma grande renovação desde a segunda 
metade da década de setenta do século passado. Além de Metahistória, de Hyden White, e O grande massacre dos gatos, de Robert Darnton, a obra Modern European Intellectual History, organizada por Dominick La Capra e Steven Kaplan e publicada em 1982, pode ser considerada uma das primeiras que colocou em discussão a nova história intelectual. Neste livro, encontra-se o artigo de Roger Chartier, Intellectual History or Sociocultural History (p. 13-15), no qual o autor lançou um conjunto de questões e preocupações comuns aos historiadores. Segundo ele, a história intelectual, ao contrário das outras histórias (econômica, social, política), apresenta uma indefinição léxica que o próprio vocábulo expõe: cada historiografia nacional possui sua própria conceitualização e, em cada uma delas, diferentes noções entram em competição.

Ao analisarmos o pensamento de um autor, não buscamos restabelecer a marcha de ideias imperturbáveis através do tempo, mas identificá-las e analisá-las no interior dos conflitos e dos debates, das alterações e mudanças de sentido que sofreram no desenrolar da história. Focalizando o papel dos intelectuais na vida política, Sirinelli (1996) afirmou que a história política e a história das ideias interagem com a história intelectual na sua atual concepção. Apontou, também, a necessidade de se atentar para o engajamento, a geração a que pertenceu e as redes às quais o intelectual se integrou para melhor entender esse agente social que possui um peso considerável na sociedade em que vive. Sobre isso, escreveu:

O meio intelectual constitui, ao menos para seu núcleo central, um "pequeno mundo estreito", onde os laços se atam, por exemplo, em torno da redação de uma revista ou de um conselho editorial de uma editora (SIRINELLI, 1996, p. 248).

Mas, em todo o caso, é possível e necessário fazer sua arqueologia, inventariando as solidariedades de origem, por exemplo de idade ou de estudos, que constituem muitas vezes a base de "redes" de intelectuais adultos. É lógico, sobretudo no caso dos acadêmicos, 
A integração latino-americana no pensamento de Aldo Ferrer...

remontar a seus jovens anos escolares e universitários, numa idade em que as influências exercem sobre um terreno móvel e em que uma abordagem retrospectiva permite reencontrar as origens do despertar intelectual e político (SIRINELLI, 1996, p. 249-250).

\section{O intelectual e o contexto de seu despertar}

Aldo Ferrer nasceu em Buenos Aires em 1927 e cursou a Faculdade de Ciências Econômicas da Universidade daquela cidade durante o primeiro mandato de Juan Domingos Perón como presidente da Argentina. É importante destacar esse aspecto porque, durante o peronismo, a Universidade se tornara um reduto de oposição ao governo, unindo professores e alunos numa causa comum. Talvez, aí, encontremos uma primeira justificativa para sua filiação ao partido União Cívica Radical (UCR), principal organização partidária de oposição.

Ainda em atuação até os dias de hoje, sua trajetória profissional é marcada pelo exercício conjunto de atividades acadêmicas e de direção, principalmente de órgãos públicos, combinando pensamento e ação. Exerceu vários cargos diretivos na administração pública, tendo sido Ministro de Economia e Fazenda da província de Buenos Aires entre os anos de 1958 e 1960, bem como Ministro de Economia da Argentina entre outubro de 1970 e maio de 1971, durante os governos dos presidentes Levingston e Lanusse, ambos nomeados em período de intervenção militar. Gerenciou, assim, a economia nacional durante um período em que a turbulência política encaminhava o país para a redemocratização e a volta do peronismo, fato que ocorreu em 1973, quando houve a eleição de Perón para Presidente da República. Desempenhou atividades junto a organismos internacionais, como o Conselho Latinoamericano de Ciências Sociais (CLACSO), entre 1967 e 1970. Durante o segundo peronismo e a ditadura militar, reservou-se às atividades acadêmicas. Quando da redemocratização, na década de 80, 
voltou à atuação político-partidária. Participou ativamente do governo radical de Raúl Alfonsín, ocupando o cargo de presidente do Banco de la Provincia de Buenos Aires, entre 1983 e 1987. Durante o mandato de Fernando de la Rúa, presidiu a Comisión Nacional de Energía Atómica (1999-2001) e, mais recentemente, tem contribuído também com governos do Partido Justicialista, como o de Nestor Kirchner. Desde março de 2006, atua como diretor de Enarsa, uma empresa estatal petroleira, criada em 2004 com o objetivo de substituir a privatizada YPF (Yacimentos Petrolíferos Fiscales).

Afora esse protagonismo na administração pública, Ferrer é uma espécie de decano dos economistas argentinos. Permanece em atividade na Universidade de Buenos Aires, onde atua como diretor da cátedra de Estratégia Econômica Internacional. Ao longo de cinco décadas de vida acadêmica, publicou várias obras, tendo se tornado uma referência do pensamento econômico latino-americano. A mais conhecida de todas, La Economia Argentina - las etapas de su desarrollo y problemas actuales, foi publicada pela primeira vez em 1963, sendo reeditada e atualizada várias vezes. A partir da edição do ano de 2004, o livro aparece com o título alterado para La economia Argentina - desde sus orígenes hasta principios del siglo XXI. ${ }^{3}$ Mais recentemente, Ferrer tem se destacado por suas críticas à globalização, tendo publicado duas obras sobre o tema, as quais analisaremos mais detalhadamente em outro item do artigo. São elas: Hechos y ficciones de la globalización - Argentina y el Mercosur en el sistema internacional e De Cristóbal Colón a Internet: América Latina y la globalización, editadas pela primeira vez em 1997 e 1999 respectivamente. ${ }^{4}$ Devido a essa postura, desde o ano de 2000 , Ferrer integra o chamado Grupo Fénix, rede de economistas argentinos que busca desenhar um modelo econômico alternativo às políticas neoliberais defendidas pelo Consenso de Washington. ${ }^{5}$

Aldo Ferrer graduou-se numa época em que os economistas e os cientistas sociais gozavam de grande prestígio, especialmente na Argentina. Além disso, formou-se numa instituição que se desta- 
A integração latino-americana no pensamento de Aldo Ferrer...

cava pela presença de grupos de discussão e pela publicação de revistas que expressavam as ideias de redes de intelectuais que iam se constituindo no seu interior. Ao contrário do que se passou nos demais países da América Latina, em que a institucionalização da economia como disciplina universitária autônoma ocorreu apenas durante a Segunda Guerra, a Faculdade de Ciências Econômicas da Universidade de Buenos Aires já havia sido instalada em 1913. Sob a forte influência de docentes como Alejandro Bunge e Raúl Prebisch, tornara-se prática recorrente, no âmbito universitário buenairense, desde os anos vinte do século passado, o debate sobre os problemas e os rumos da economia nacional, bem como o manejo de dados estatísticos. ${ }^{6}$ Decorrente dessa formação, não poucos egressos da faculdade ocuparam cargos técnicos na burocracia estatal e em empresas privadas.

A presença de uma elite intelectual nos anos cinquenta na Argentina, da qual Aldo Ferrer participava, integrada por economistas e cientistas sociais, deve-se, em muito, à figura de Raúl Prebisch. Este, juntamente com outros colaboradores, atuou de maneira decisiva na formulação de planos e políticas econômicas durante o governo de Justo (1932 a 1938) e nos inícios dos anos quarenta. ${ }^{7}$ Foi expulso da função pública, que ocupava há mais de uma década, pelo governo peronista ${ }^{8}$, tendo deixado o país em 1948 para ocupar o cargo de secretário-executivo da Comissão Econômica para a América Latina (Cepal), com sede no Chile.

Raul Prebisch exerceu forte influência sobre seus pares e conterrâneos, principalmente através da obra que fundou o pensamento cepalino, El desarrollo económico de la América Latina y algunos de sus principais problemas, publicada em 1949. Ao defender a industrialização baseada na substituição de importações e não na produção industrial voltada ao mercado internacional, mais competitivo, seu discurso estimulou, ao longo dos anos cinquenta, o debate em torno das reformas estruturais que aumentassem o nível de renda interna nos países e que criassem mercado para os produtos da indústria nacional que substituía importações. 
Ainda como docente da Faculdade de Ciências Econômicas, Prebisch empenhou-se na formação e qualificação de quadros técnicos estatais, estimulando a realização de cursos de doutorado na Universidade de Harvard pelos funcionários do Ministério da Fazenda e do Banco Central. Os resultados dessa ação passaram a ser sentidos a partir de 1955, após a queda de Perón, e na década seguinte, quando outra elite técnica estatal - da qual Aldo Ferrer é um dos integrantes -, agora com vínculos e formação internacionais, seria a principal gestora da inserção do Estado argentino no cenário econômico internacional. ${ }^{10}$ Isso ocorreu, também, porque, após 1958, os intelectuais cepalinos haviam percebido o esgotamento do modelo de desenvolvimento econômico baseado na substituição de importações com um viés nacionalista. Após terem sido atingidas as etapas iniciais de instalação de complexos industriais, impunha-se avançar em direção à produção de bens intermediários e de bens de capitais. Sendo assim, o grupo passou a defender a adesão, da Argentina, ao Fundo Monetário Internacional e ao Banco Mundial, bem como a criação de instituições estatais capazes de colocar em prática o desenvolvimentismo.

\section{O Desenvolvimento e a integração}

O desenvolvimentismo pode ser considerado como um "clima de ideias" que se fez fortemente presente na América Latina a partir do fim dos anos cinquenta. Ele circulava com muita força nos meios intelectuais latino-americanos, pois defendia posições apresentadas pela Cepal e retirava, mesmo que contraditoriamente, subsídios de uma obra que fazia grande sucesso na época, denominada Etapas do Desenvolvimento Econômico. De autoria de W.W. Rostow, o livro fora publicado em 1959 pela primeira vez. ${ }^{11}$ Carlos Altamirano elucida esse aspecto contraditório:

En cierto modo, la idea del desarrollo fue un sustituto y una variante de la idea del progreso. Como ésta, promovía el 
cambio y contenía una interpretación del proceso histórico en términos de etapas sucesivas de mejoramiento creciente de la vida individual y colectiva. Ambas, igualmente, estaban volcadas hacia el futuro y celebraban el avance de la ciencia y de la técnica. Ellas, sin embargo, no eran inmediatamente permutables. Para el pensamiento desarrollista, el cambio por excelencia, la industrialización, no sobrevendría por evolución económica espontánea. No sería, en otras palabras, resultante del liberalismo económico, la doctrina y la práctica que históricamente había sido indisociable de la idea del progreso. La idea del desarrollo, por el contrario, reposaba en la convicción de que los países de la periferia no saldrían del atraso si confiaban en repetir, con retardo, la secuencia histórica de las naciones adelantadas. Y El agente por excelencia de ese impulso debia ser El Estado (ALTAMIRANO, 2005, p. 129).

A revolução Cubana e seus desdobramentos nos inícios da década de sessenta serviram para reforçar o desenvolvimentismo entre certos círculos intelectuais na América Latina nos anos sessenta. Ao defender a industrialização acelerada, a tecnificação do setor agrícola e a reforma agrária moderada - fatores que permitiriam um crescimento econômico sustentado e uma distribuição mais equilibrada da riqueza -, ele se apresentou, para alguns círculos, naquele contexto intelectual, como alternativa reformista e progressista para os problemas que assolavam a América Latina. ${ }^{12}$

A integração econômica, nesse contexto de ideias e projetos, aparecia como complemento indispensável a essa política de desenvolvimento industrial. A constituição da Cepal, nos prelúdios dos anos cinquenta, já respondera a novos pleitos relativos à integração regional, os quais defendiam a substituição da união política - o que, aliás, fora reforçada pela criação da Organização dos Estados Americanos (OEA) - pela unidade econômica. Sua finalidade, como comissão econômica regional, era coordenar políticas programadas para promover o desenvolvimento econômico da América Latina. Nesse sentido, o organismo propusera, em sua primeira reunião, que os estados latino-americanos se agrupassem numa série de 
uniões aduaneiras sub-regionais, as quais poderiam se fundir numa entidade maior quando estivessem mais bem articuladas.

A partir de 1958, por razões econômicas e políticas, a Cepal mudou de postura. Seus teóricos passaram a acreditar que a integração econômica de toda a América Latina poderia ser um contrapeso à hegemonia dos Estados Unidos e propiciar, aos estados latino-americanos, um maior poder econômico regional e uma influência econômica coletiva mais significativa. Por outro lado, perceberam que o modelo de desenvolvimento econômico baseado na substituição de importações com um viés nacionalista começava a se esgotar. Assim, após as etapas iniciais de instalação de complexos industriais terem sido atingidas, era necessário avançar em direção à produção de bens intermediários e de bens de capitais. Para tanto, era fundamental a ampliação de mercados, o que poderia ser alcançado através da integração.

Compondo o contexto no qual Aldo Ferrer iniciou suas atividades intelectuais e de economista, deve-se mencionar, ainda, o desencadeamento do processo europeu de integração, com a instalação da Comunidade Econômica Europeia em 1957. Isso serviria tanto como estímulo para a formulação de um projeto similar latinoamericano, quanto como modelo referencial para as ideias desenvolvimentistas. Assim, sob influência da iniciativa europeia, em 1959, instalou-se o Banco Interamericano de Desenvolvimento (BID), como elemento de ímpeto e de apoio à integração econômica da América Latina e, em fevereiro de 1960, sete estados latino-americanos firmaram o Tratado de Montevidéu, estabelecendo a Associação Latino-Americana de Livre Comércio - ALALC, visando à ampliação do fluxo comercial entre os países signatários. ${ }^{13}$

\section{A Revista Desarrollo Econômico $(D E)$ e a formação de redes}

Aldo Ferrer é um intelectual que se caracteriza, ao longo de sua vida profissional, por estimular a formação, bem como por 
A integração latino-americana no pensamento de Aldo Ferrer...

participar ativamente de redes de intelectuais. Uma de suas primeiras e, talvez, mais significativas iniciativas nesse sentido deu-se no final dos anos cinquenta, quando, ocupando o cargo de Ministro de Economia e Fazenda da província de Buenos Aires, criou condições para que se instalasse o Instituto de Desarrollo Económico y Social (IDES), associação civil sem fins lucrativos, de índole acadêmica, dedicada ao estudo de temas econômicos, políticos e culturais.

O IDES foi fundado em 1960 por um grupo de cientistas sociais que buscava estimular e promover o trabalho interdisciplinar no meio acadêmico. Um ano após, Ferrer assumiu a responsabilidade pela edição da Revista Desarrollo Econômico (DE), introduzindo-lhe a mesma marca e tornando-a o seu meio de comunicação com a sociedade.

A Revista Desarrollo Econômico vem sendo publicada semestralmente de forma ininterrupta desde seu lançamento até os dias de hoje, tendo resistido a inúmeras conjunturas políticas e econômicas adversas. No editorial do volume em que foram comemorados os vinte e cinco anos da Revista, o Comitê Editorial fez referência à iniciativa de Aldo Ferrer para o surgimento do Instituto e da Revista:

El IDES y nuestra revista nacieron, hace veinticinco años, de una conjunción de esfuerzos de científicos sociales. El aporte inicial provido esencialmente de tres grupos: por un lado, un conjunto de economista que acompañaron la gestión de Aldo Ferrer como ministro de Economía de la provincia de Buenos Aires, entre los que estaba Norberto González, primer presidente del IDES; por otro, historiadores, sociólogos y politólogos nucleados en torno del Instituto de Sociología de la Universidad de Buenos Aires; y, por último, por investigadores del Instituto Di Tella - por entonces la única institución privada importante de investigación en ciencias sociales en el país (COMITÊ EDITORIAL, 1986, p. 483).

As palavras dos editores permitem perceber que tanto o IDES quanto a Revista DE estavam abertos à multidisciplinaridade. Além 
disso, é possível vislumbrar qual era o perfil do intelectual que publicava na Revista: um sujeito cuja característica básica deveria ser a de um acadêmico voltado à investigação documental e engajado no processo político. A partir dessa postura, que fazia parte da concepção de intelectual na época, os autores dos artigos deveriam realizar análises interpretativas e críticas da realidade, deixando para trás os ensaios de ordem cultural e filosófica. As contribuições à revista deveriam estar baseadas em pesquisas científicas, realizadas a partir de rigor metodológico.

Considerando a origem do periódico, os intelectuais que predominantemente publicaram na $D E$ foram do grupo reformista, ou seja, tinham posições de crítica em relação à política nacional, procuravam transformar a realidade local, mas sem o radicalismo ideológico dos revolucionários.

O periódico citado surgiu num período de "pandemônio ideológico" (KAPLAN, 1979, p. 36) e de grande instabilidade política na Argentina. O país enfrentava um doloroso processo de reconhecimento de sua condição de nação subdesenvolvida e latino-americana. Até aquele momento, o país acreditara acompanhar o processo histórico semelhante ao de outras áreas coloniais, como Austrália e Canadá, que atingiam níveis de desenvolvimento próximos aos dos países industrializados.

Apesar de Perón ter sido deposto pela chamada Revolução Libertadora, em 1955, o peronismo continuava vivo como força política. A coalizão que derrubara o presidente e que buscara restituir, à grande burguesia, o pleno controle da vida nacional, sofrera fraturas internas após a vitória e não conseguia resistir à pressão das massas, nem destruir o movimento operário organizado e as alternativas de esquerda. O general Pedro Aramburu, que governara ditatorialmente desde 55, fora obrigado a convocar, em 1956, eleição presidencial, da qual saiu eleito Arturo Frondizi.

Este, eleito pela União Cívica Radical (UCR), realizou um governo que pactuou com Perón desde o exílio, no sentido de possibilitar o retorno do peronismo à cena política. Por outro lado, deu 
A integração latino-americana no pensamento de Aldo Ferrer...

continuidade à política econômica do governo anterior ${ }^{14}$ e à posição das forças armadas como definidoras da linha político-ideológica do governo. Essa contradição foi responsável pela sua deposição em 1962, sendo seu governo concluído pelo Presidente do Senado, Jose Maria Guido, que governou sob a tutela das forças armadas, sem Congresso e sem liberdade política.

Em sintonia com o clima de que a América Latina devia e podia superar seu subdesenvolvimento e seguindo os propósitos de debate acadêmico e de intervenção cultural, a DE buscou colocar, no centro da reflexão, a problemática do desenvolvimento e da modernização. Além do viés econômico e da valorização das Ciências Sociais - características apontadas já em seu nome -, uma forte influência do desenvolvimentismo foi exercida sobre os fundadores e responsáveis pela primeira década de edição, como também sobre toda a rede de intelectuais que com ela contribuíram.

A temática da integração apareceu no periódico com um significado claramente econômico. Nele, dava-se destaque à necessidade da formação de um bloco comercial regional, aspecto defendido pela Cepal naquele momento, a fim de estimular o desenvolvimento latino-americano. Afora a publicação de artigos avulsos em alguns números, a integração foi focalizada especialmente num dos volumes da Revista, o IV, n. 14-15, em que há, inclusive, um artigo de autoria de Aldo Ferrer. O volume publicou, ao todo, nove artigos, os quais mostravam estar influenciados por duas experiências de integração regional que marcaram aqueles primeiros anos da década de sessenta: a Comunidade Econômica Europeia, formada em 1957, e a ALALC, instituída em $1960 .{ }^{15}$

A iniciativa de formação da ALALC foi apoiada pela Cepal, que, como vimos, acreditava que a integração comercial se constituía numa oportunidade a mais para impulsionar o desenvolvimento econômico e social da região. Sem ignorar a necessidade de que as nações associadas solucionassem seus problemas estruturais e adequassem seus interesses à política regional, os cepalinos percebiam 
que os nacionalismos estreitos deveriam ser abandonados. De fato, como argumentava Raul Prebish, principal mentor e dirigente da Cepal:

A política de integração latino-americana, a ação regional e, em geral, a cooperação internacional não constituem alternativas às reformas em nossa estrutura econômica e social. (...) Mas será menos difícil acometer esta ingente tarefa em uma economia que cresça aceleradamente, com todo o alento de uma política de integração e de cooperação continental e internacional audaz e clarividente (PREBISH, 1965, p. 192).

Entretanto, o principal fator propulsor à formação da ALALC, naquele momento, não foi o discurso cepalino, mas sim um problema específico na relação comercial entre Argentina, Brasil, Chile e Uruguai. O fluxo de comércio entre esses quatro países encontrava-se em declínio desde o final da Segunda Guerra Mundial. Apesar de, a partir de 1948, alguns canais de comércio bilaterais terem se intensificado com o intuito de solucionar o déficit na balança de pagamentos, na segunda metade da década de 50, Argentina, Chile e posteriormente o Brasil, em níveis diferentes, iniciaram um processo de liberalização e multilateralização de suas relações comerciais, o que provocou um declínio ainda maior do comércio entre esses países do cone sul. ${ }^{16}$

Findados, em 1962, os ciclos iniciais de negociações da Associação, os resultados atingidos "deram razão para abrigar um cauteloso otimismo" e "inclusive, depois de tomar em conta estas considerações, existem razões para concluir que a ALALC teve um princípio promissor" (DELL, 1981, p. 231).

$\mathrm{O}$ avanço na direção do cumprimento das metas acordadas fora substancial e, até meados dos anos sessenta, o fluxo comercial entre os países membros alcançou o nível máximo em comparação ao período anterior à assinatura do tratado, após a Segunda Guerra Mundial. Na segunda metade da década de sessenta, ocorreu um 
A integração latino-americana no pensamento de Aldo Ferrer...

sensível progresso nas relações intrarregionais, através de novas disposições financeiras e de acordos de complementação bilaterais ou multilaterais. ${ }^{17}$ Tais acordos, que beneficiaram principalmente as empresas multinacionais que haviam se instalado nos parques industriais dos países integrantes da ALALC, possibilitavam a liberalização do comércio de um grupo específico de artigos e estabeleciam ferramentas de promoção de comércio recíproco. ${ }^{18}$

É nesse contexto positivo em relação às possibilidades da integração econômica da América Latina que a DE publicou o volume a que nos referimos anteriormente. Nele, Aldo Ferrer assinou o artigo "Modernización, desarrollo industrial e integración latinoamericana", no qual apresenta as linhas principais do seu pensamento desenvolvimentista em relação à questão da integração. Nos parágrafos iniciais, define a - para ele - necessária e indispensável relação existente entre os três conceitos que aparecem no título do artigo e, também, o papel e significado de cada um, todos com claro conteúdo econômico. Ao afirmar que

entiendo por modernización la asimilación de las técnicas contemporáneas en toda la actividad económica con la consecuente transformación de las relaciones sociales de producción y elevación de los patrones culturales de la población (FERRER, 1964, p. 1) ${ }^{19}$,

o autor defende que a modernização depende fundamentalmente da industrialização, incluindo as manufaturas de crescimento mais dinâmico e tecnologia mais complexa. E, para que isso ocorra, é fundamental que se realize a integração regional. Diz:

Se sostiene aqui que la integracion latinoamericana es un requisito fundamental para que el ritmo de industrialización sea lo suficientemente rapido como para permitir una transformación acelerada de las estruturas productivas (FERRER, 1964, p. 1-2). 
Logo a seguir, em seu texto, Ferrer argumenta novamente sobre a importância da integração do mercado latino-americano para a industrialização:

La formación de um gran mercado latinoamericano de más de 200 millones de habitantes es condición indispensable para la expansión de las indústrias dinámicas que requiéren operar con plantas de gran dimension. Especialmente, el desarrollo industrial de los países medianos y pequeños de la América Latina está fuertemente condicionado por la ampliación de las fronteras de sus estrechos mercados internos. Asimismo, la formación de un gran mercado regional con movilidad de recursos financieros es condición importante para concentrar recursos en industrias que requieren grandes inversiones locales (FERRER, 1964, p. 7).

Para este intelectual, porém, para que a integração promova o desenvolvimento, é necessário que seja incentivada a instalação de indústrias estratégicas para o desenvolvimento, tais como a automobilística, as de produtos químicos, de aço e suas manufaturas.

A comparação entre o processo de integração latino-americana, que se iniciava naquela época com experiências como a formação da ALALC, e o que ocorria na Europa era um tema que interessava aos intelectuais de então. Ferrer, não fugindo da tendência, aponta as desvantagens em que se encontra a América Latina, afirmando que, ao contrário do que acontecia na Europa, aqui se pretendia integrar economias subdesenvolvidas que se encontravam totalmente desvinculadas entre si. Para este intelectual, o fato de apenas $10 \%$ do comércio externo realizado pelos países latino-americanos resultar das trocas inter-regionais, a ausência completa de meios de comunicação e transporte unindo os países e a dependência de importações extra-regionais de produtos industriais de tecnologia mais complexa eram os problemas principais que a integração deveria resolver para atingir sua função de promover o desenvolvimento. ${ }^{20}$ 
A integração latino-americana no pensamento de Aldo Ferrer...

Ferrer comungava do diagnóstico que unia os intelectuais que publicaram na $D E$, ou seja, o entendimento de que o processo de integração latino-americano "debe ser coincidente con un profundo cambio de las estructuras socio-políticas de la sociedad tradicional y dependiente que determinan el estancamento" (FERRER, 1964, p. 9). Esses intelectuais enfatizavam os problemas apresentados pela estrutura econômica e as deficiências das iniciativas políticas dos países da América Latina. Para eles, o desafio a vencer era mais de ordem interna do que externa, ao contrário do que defendiam alguns intelectuais que justificavam o atraso latino-americano pela presença do imperialismo e da dependência econômica. Nesse sentido, temos o artigo de Leopoldo Portnoy, professor da Universidade de Buenos Aires, "Los pólos de desarrollo y la integración de América Latina", no qual o autor preocupa-se em destacar a diferença dos resultados que são obtidos com a instalação de uma grande indústria, que atua como pólo de desenvolvimento tanto por sua dimensão quanto por sua influência, em uma economia desenvolvida e em outra, menos desenvolvida.

El proceso de concentración que se opera en un país de infraestructura incompleta, como consecuencia de la implantación de un pólo de desarrollo, v.gr.: un complejo siderúrgico, es tremendamente más acelerado que el que se puede dar en países desarrollados en los que representa nada más que una unidad agregada en un esquema ya establecido (PORTNOY, 1964, p. 2).

Seguindo essa linha de interpretação, Camilo Dagum, Decano da Faculdade de Ciências Econômicas da Universidade Nacional de Córdoba, também postulava a integração econômica "como solución permanente y de extraordinárias perspectivas econômicas y sociales para el desarrollo sustenido y a altas tasas em América Latina" (DAGUM, 1964, p. 24). Para ele, o alto índice de população a ser incorporado no processo produtivo e no mercado de consumo em 
todos os países latino-americanos são fatores que potencializam os bons resultados da integração na América Latina. Diz o economista:

Por otra parte, el proceso de industrialización de los países latinoamericanos está adquiriendo una capacidad de producción que tiende a sobrepasar la capacidad de demanda actual de sus mercados nacionales y exige un volumen creciente de insumos y equipos de capital importados (DAGUM, 1964, p. 24).

Antes, porém, alertava:

En síntesis, podríamos armar nuestro pensamiento a partir de la idea motriz del proceso de cambio de estructura. (...) Para comenzar, una reforma profunda del régimen de tenencia de la tierra que abra camino a una mayor productividad del trabajo y del capital con respecto a la unidad de la superficie (DAGUM, 1964, p. 23).

A integração regional via ALALC foi perdendo sua eficácia até ser extinta em 1980. Outros blocos comerciais, de caráter subregional, foram se formando na América Latina, como, por exemplo, o Pacto Andino, instituído em 1969. No que diz respeito aos países meridionais da América do Sul, nos quais se insere a Argentina, essa prática foi prejudicada pelo longo período de ditaduras militares que a região conheceu. Com a redemocratização, entretanto, a ideia de integração voltou a ser discutida e defendida, resultando na constituição do Mercado Comum do Sul - Mercosul. Com a adesão de Argentina, Brasil, Paraguai e Uruguai, a formalização do bloco ocorreu com a assinatura do Tratado de Assunção, em março de 1991, o qual instituía uma união alfandegária de países. ${ }^{21}$

Aldo Ferrer tem se posicionado em relação ao Mercosul, procurando explicar as razões para suas crises, seus sucessos e seus fracassos. $\mathrm{O}$ fator que mais se destaca em sua análise é a relação que 
A integração latino-americana no pensamento de Aldo Ferrer...

estabelece entre a criação do bloco comercial e as diretrizes da globalização, corporificadas no Consenso de Washington. Nessa relação, estariam as razões para a debilidade desse Mercado Comum.

Demonstrando que sua maneira de entender a realidade presente é processual e, portanto, ainda influenciada pelas ideias que vigoravam durante o período de sua formação intelectual, ele considera que a globalização não é um fenômeno recente, mas existe há mais de cinco séculos. Ela é decisiva para avaliarmos as possibilidades de sucesso da integração de países latino-americanos. Por isso, no livro De Cristóbal Colón a Internet: América Latina y la globalización, dedica a segunda parte à apresentação de

un panorama sumario de las circunstancias que determinaron la inserción de nuestros países en el orden mundial desde la conquista hasta la actualidad. Se sugiere aquí que los problemas actuales y las perspectivas futuras de America Latina son resultado de la resolución del contrapunto realidad interna-contexto mundial a lo largo del tiempo (FERRER, 1999, p. 56).

Em sua avaliação, as reformas que se processaram em alguns países da América Latina na década de noventa, as quais buscavam atender o Consenso de Washington, possibilitaram avanços mais aparentes do que reais às economias dos países envolvidos, principalmente no que tange ao equilíbrio fiscal e controle da inflação. Considera, entretanto, que as respostas aos desafios do desenvolvimento em um mundo global são piores do que no passado, principalmente porque colocam as economias em extrema dependência financeira externa. Ao finalizar, demonstra o vínculo que mantém com suas raízes cepalinas e critica o ostracismo em que foram colocados a Cepal e Raúl Prebisch (intelectual a quem dedica o livro). Apesar de reconhecer as transformações constantes e irreversíveis do processo histórico, destaca o latino-americanismo e a importância do estado planificador como as contribuições mais significativas e modelares da Cepal: 
Frente al fracaso de la estratégia neoliberal y las consecuencias sobre el bienestar y la seguridad de los países latinoamericanos, en la actualidad las contribuiciones de la CEPAL vuelven a recuperar su relevancia para fundar buenas respuestas a la globalización de mundo contemporáneo.

Ese legado no radica principalmente en las teorias sobre la distribución de los frutos del progreso técnico, los términos de intercambio o la propagación de los ciclos. Estas contribuiciones están asociadas a la época en la que surgieron; los tiempos han cambiado. El aporte de la CEPAL consiste más bien en la actitud, en la postura adoptada para abordar el tratamiento de los problemas de la realidad latinoamericana y formular propuestas. Esa postura tiene tres rasgos predominantes: la insistencia de observar el mundo desde la perpectiva de la realidad latinoamericana..., rechazar el fatalismo de los mercados, es decir, de cualquier versión fundamentalista de la globalización... y el desarrollo descansa en los mercados y la iniciativa privada orientados por la acción pública para compatibilizar la apertura con el desarrollo y el comando del proprio destino en el mundo global (FERRER, 1999, p. 96-97).

Em Hechos y ficciones en el sistema internacional - Argentina y el Mercosur en el sistema internacional, Aldo Ferrer dedica-se especialmente à questão da integração regional. É importante que se diga que a obra foi escrita num momento em que ainda havia uma avaliação otimista em relação ao Mercosul, tanto por parte dos intelectuais, quanto dos políticos e da sociedade em geral.

Apesar de reconhecer que o comércio entre os países do Mercosul, principalmente entre Brasil e Argentina, ganhara vigor nos anos de funcionamento do bloco que compreendiam sua análise (cerca de quinze anos) e que alguns obstáculos históricos às boas relações comerciais entre os dois países haviam sido superados, Ferrer considera que estão pendentes, entretanto, outras questões que são requisitos essenciais para o êxito de um bloco regional. São eles: a autodeterminação dos Estados-membros, o equilíbrio 
A integração latino-americana no pensamento de Aldo Ferrer...

no nível de desenvolvimento social dos países a convergência das estratégias nacionais e afinidades na visão de mundo. Para ele, os primeiros anos de funcionamento do Mercosul constituem o período de graça da relação argentino-brasileira e alguns resultados positivos foram alcançados. Porém, ao final da década de noventa, com a crise econômica assolando os dois países, emergem as consequências dos pecados originais do processo, que são: a dependência financeira, comercial e de investimentos externa ao bloco, a pobreza e a exclusão social, as assimetrias nas estratégias nacionais e as divergências quanto à inserção internacional.

Passada quase outra década de vigência do Mercosul, quando as crises e as dificuldades se sobressaíram aos resultados positivos, ocasionando um entrave para a consolidação de uma área de livre comércio, Ferrer ainda vê com otimismo a existência do bloco. Porém, seus pressupostos latino-americanistas e estruturalistas dos anos sessenta e setenta ainda orientam sua concepção de integração. Em recente entrevista, concedida ao periódico Carta Maior no contexto da crise econômica que assola a economia mundial desde meados de 2008, assim se manifestou:

O avanço da integração no MERCOSUL e a ampliação das relações políticas e diplomáticas na UNASUL abrem a possibilidade de ações conjuntas frente à crise. Sem dúvida, porém, essa possibilidade é limitada pelas assimetrias de escala, bem como entre níveis relativos de desenvolvimento, ademais, de contextos e políticas macro-econômicas distintas. O fato é que cada país tem a responsabilidade primeira de responder à turbulência externa.

(...) Nossos países não têm possibilidade alguma de mudar o mundo, mas temos a responsabilidade intransferível de decidir o lugar que ocuparemos nele. Historicamente não escolhemos bem. Por isso, dois séculos depois da independência continuamos a ser economias periféricas e subdesenvolvidas.

Temos que viver com o que temos; assentar nosso crescimento na poupança interna; defender nossos recursos; consolidar 
equilíbrios macro-econômicos; repartir melhor a renda e a riqueza; transformar a estrutura produtiva; ampliar o grau de educação e promover a integração das estruturas produtivas nacionais. Essa empresa é, em primeiro lugar, um desafio que cada país deve assumir com seu povo.

¿Qué enseñanzas nos dejan los acontecimientos actuales a países en desarrollo, como Argentina y los hermanos de América Latina? (...) Así como Keynes vuelve al Norte, aquí, en el Sur latinoamericano, vuelven Raúl Prebisch, Celso Furtado y los otros fundadores del estructuralismo latinoamericano, como referencia esencial para enfrentar con éxito los desafíos que plantea la emergencia de un nuevo orden mundial (REDAÇÃO CARTA MAIOR, 2008, p. 1).

\section{Conclusão}

Aldo Ferrer é um intelectual a quem a expressão "silêncio dos intelectuais" não se aplica, pois mantém uma postura interativa com a sociedade em que vive, buscando contribuir, também no plano da ação política, para a superação de problemas e para a sua transformação.

Corroborando com o que Sirinelli afirma sobre a importância do período de formação do intelectual, as ideias de Prebisch e da Cepal até hoje calam fundo em seu imaginário. Sua concepção de ordem mundial é muito influenciada pela necessidade de desenvolvimento autônomo nacional e de mudança de estruturas para se atingir o desenvolvimento. Por isso, até os dias atuais, sua postura crítica em relação ao mundo globalizado e sua defesa em relação ao Mercosul guardam coerência com suas históricas preocupações com o desenvolvimento regional e com o latinoamericanismo. Cabe ressaltar outra característica de sua atuação como intelectual: sua afeição à atuação em "redes". No passado, foi agente propulsor de intelectuais que se organizaram em torno da corrente desenvolvimentista. No presente, participa de grupos 
que visam subsidiar e orientar a política energética e ambiental argentina, contribuindo para a recuperação econômica de seu país.

Por fim, podemos concluir que, tendo vivenciado várias conjunturas econômicas nacionais e internacionais, bem como atuado sob duas ordens mundiais distintas, ele é um intelectual comprometido essencialmente com a problemática latino-americana, buscando compreendê-la e transformá-la a partir dos problemas e do contexto atuais, sem, no entanto, esquecer a importância das contribuições e das experiências já vividas no passado.

\section{Latin-American integration in Aldo Ferrer's thought}

Abstract: The present article analyses the theme of economic integration in Latin America, with main focus on the formation of trading communities, and connected to the experiences of Aldo Ferrer. The Argentinean scholar began writing and working as an economist in the 50's, a time when most intellectuals were engaged in politics, and continues to work to this day, when economists seem rather silent. This article's objective was to study Aldo Ferrer's performance in the matter of trading communities from the creation of the first regional economic community in Latin America (Latin American Free Trade Association-ALALC, in 1960) to recent years, when the creation of Mercosur stands out. The analysis aims at identifying whether there were changes in his thoughts and actions considering the different scenarios and world order he has experienced along his life time.

Keywords: Intellectuals. Aldo Ferrer. Integration. Latin America. Argentina.

\section{Notas:}

${ }^{1}$ Um dos autores que utiliza essa denominação é Carlos Guilherme Mota. Ver, de sua autoria, Ideologia da Cultura Brasileira. (MOTA, 1994, cap. 5).

${ }^{2}$ Mais recentemente, Said (1993, p. 6), mesmo reconhecendo a importância da contribuição de Gramsci para definir o papel do intelectual na sociedade moderna, revisou essa concepção de intelectual orgânico, apontando para sua função pública específica. Para ele, o intelectual é alguém capaz de "levantar publicamente questões embaraçosas, confrontar ortodoxia e dogma (preferivelmente a produzi-los), alguém que não possa ser facilmente cooptado por governos ou corporações, e cuja razão de ser é representar todas aquelas pessoas que são rotineiramente esquecidas ou varridas para debaixo do tapete". ${ }^{3}$ A última versão se encontra em sua $4^{a}$ edição. Foi publicada no Brasil, em 2006, pela editora FUNAG/Campus. 
${ }^{4}$ Ambos os livros foram publicados pela editora Fondo de Cultura Económica, cuja sede está em Buenos Aires.

${ }^{5}$ Em 1989, em Washington, realizou-se uma reunião entre economistas neoliberais cuja pauta era a economia da América Latina. Firmaram-se, então, 10 pontos consensuais que serviram, posteriormente, como condição básica para a concessão de créditos para os países latinos. Esses pontos ficaram conhecidos como Consenso de Washington. ${ }^{6} \mathrm{~A}$ Faculdade de Ciências Econômicas contava com uma revista própria (Revista de Ciencias Económicas), publicada desde 1913, quando surgiu como iniciativa dos estudantes. A partir de 1920, ela passou a ser o órgão oficial do Centro de Estudantes da faculdade e do Colégio de Contadores Públicos e de Doutores em Ciências Econômicas. A outra revista (Revista de Economia Argentina), criada pelo engenheiro e professor de geografia e estatística, o católico Alfredo Bunge, também congregou vários intelectuais economistas, preocupados com o manejo de estatísticas e cálculos matemáticos a partir dos anos vinte do século passado. Ver mais em J. Pantaleón (in Neiburg, Plotkin, 2004).

${ }^{7}$ Em 1935, criaram o Banco Central e foram responsáveis pelo fracassado Plan Pinedo, que promovia a proteção limitada a certas indústrias.

${ }^{8} \mathrm{~A}$ maioria de seus colaboradores dedicou-se à atividade privada para retornar a um lugar protagônico como funcionários estatais após a caída de Perón, em 1955.

${ }^{9}$ Instalada como escritório regional da $\mathrm{ONU}$, a Cepal contava com a colaboração de intelectuais latino-americanos que definiram a América Latina e seu desenvolvimento como objeto primordial de sua reflexão. Com a autoridade de um organismo internacionalmente reconhecido, em seus primeiros anos, produziu um pensamento autóctone latino-americano que se concentrou em criticar a orientação liberal vinda das nações desenvolvidas e em defender a necessidade de reformas estruturais na economia e na sociedade dos países periféricos. De acordo com sua posição estruturalista, contrária ao monetarismo dos países centrais do capitalismo, ela defendeu o fim da divisão internacional do trabalho que separava países industrializados centro - de países não industrializados - periferia. A seu ver, o crescimento econômico, iniciado por volta de 1880 e orientado para as exportações de bens primários, era a causa do estancamento e de atraso da região. Os países da América Latina deveriam implementar, com a forte coordenação e planejamento do Estado, a industrialização substitutiva de importações, única alternativa ao desenvolvimento da região. Para tanto, era necessário estimular a relação da agricultura com a indústria, fazendo com que esta absorvesse a mão-de-obra excedente do mundo rural e visse aumentadas as capacidades de consumo do mercado interno e, por extensão, de acumulação de capital. Essas condições seriam alcançadas através da implementação e algumas reformas na estrutura produtiva, principalmente daqueles que atuariam no combate à concentração da renda e da propriedade. Ver mais em Aleixo (1970) e Dell (1981). 
${ }^{10} \mathrm{O}$ nacionalismo econômico e a política externa de Perón haviam afastado a Argentina do cenário internacional e impedido que participasse dos organismos internacionais que foram se constituindo, tais como o FMI e o Banco Internacional de Reconstrução e Fomento, antecessor do Banco Mundial.

${ }^{11}$ A obra levava um sugestivo complemento no título: um manifesto não comunista. Foi escrita por um professor de História Econômica do Instituto Tecnológico de Massachussets, o qual identificava um conjunto de cinco etapas que deveriam ser vencidas a fim de que uma sociedade atingisse o desenvolvimento. Saindo do estágio de sociedade tradicional para o de moderna, que denominou de Era do consumo de massa, eram necessários certos níveis de acumulação de capital, crescimento do produto interno bruto, investimentos, dentre outros elementos, para superar as fases intermediárias que foram denominadas de Precondições para o arranco, Arranco e Marcha para a maturidade (ROSTOW, 1971).

${ }^{12} \mathrm{O}$ desenvolvimentismo, como uma variante da ideia de progresso, surgia como contraponto a uma proposta mais radical, também muito aceita no meio intelectual, que era a da revolução, ou mudança radical e rápida das estruturas socioeconômicas. ${ }^{13}$ Assinaram o Tratado, em 1960, Argentina, Brasil, Chile, México, Paraguai, Peru e Uruguai. O Equador aderiu em 1962, enquanto a Venezuela o fez em 1966 e a Bolívia, em 1967.

${ }^{14} \mathrm{Em}$ seu governo, Frondizi impulsionou o desenvolvimento, dando continuidade ao processo de industrialização por substituição de importações através da implantação de indústria pesada e de infraestrutura e na exploração de recursos naturais (petróleo e gás), associando-o, entretanto, a uma maior abertura econômica e aos investimentos externos.

${ }^{15}$ Os artigos que compõem a edição de 1964, volume IV, são: Antecedentes y perspectivas de la Asociación Latinoamericana de Libre Comercio (José María Dagnino Pastore), México y la integración económica latinoamericana (Phillippe C. Schmitter y Ernst B. Hass), Problemas de industrialización con restricciones en el sector externo (Javier Villanueva), Los polos de desarrollo y la integración de América Latina (Leopoldo Portnoy), Modemización, desarrollo industrial e integración latinoamericana (Aldo Ferrer), Integración política de América Latina: validez de una ideología (Lilian O'Connell de Alurralde), La integración y el crecimiento económico en América Latina (Camilo Dagum).

${ }^{16}$ Os acordos bilaterais, de caráter discriminatório, ou seja, não extensíveis às demais nações, consistiam, até então, em uma das ferramentas mais usuais no fomento de comércio. Esse recurso, porém, não era mais viável desde a formação do General Agreement of Tariffs and Trade (GATT) ao qual aderiram aqueles países, excetuandose a Argentina. Tratava-se de um acordo que buscava regulamentar o comércio mundial sob uma perspectiva de multilateralismo. Sua cláusula fundamental era a de Nação mais favorecida, ou seja, os benefícios comerciais concedidos a um país 
signatário do Acordo deveriam ser estendidos, automaticamente, aos demais signatários, o que resulta em sua natureza não discriminatória. Assim, o bilateralismo desempenhava, até certo ponto, o papel de um protecionismo em uma área ampliada e se podia admitir, dadas as características das economias nacionais em questão, que seu desaparecimento acarretara redução no nível de atividade. Dessa forma, os Quatro Países do Sul estavam impedidos de adotar as medidas convencionais para recuperar o déficit na balança de pagamentos de suas transações. A saída apontada por uma série de estudos realizados entre os anos de 1957-1958 seria o estabelecimento de um bloco econômico que empregaria uma das cláusulas de exceção do GATT, tornando-se possível adotar medidas discriminatórias. Essa proposta foi aceita pelos governos e iniciaram-se negociações para a formação de uma Área de Livre Comércio na América do Sul.

${ }^{17}$ Com o intuito de fomentar a relação direta entre os bancos, de minimizar a necessidade de intermediários externos que financiassem os acordos comerciais e de melhorar o acesso ao crédito para o comércio recíproco entre países com uma balança de pagamentos deficitária, em 1965, foi firmado, entre os Bancos Centrais, um convênio sobre pagamentos multilaterais e créditos recíprocos ao qual aderiram todos os membros da ALALC além da República Dominicana. Um resultado importante deste mecanismo foi a progressiva interconexão entre os bancos locais e o fomento do comércio recíproco que surgia da disponibilidade de crédito.

${ }^{18}$ Não obstante, o sucesso atingido nesse primeiro período foi seguido por uma paralisação das negociações, que pode ser atribuída a três fatores principais: deficiências operacionais inerentes ao próprio tratado, falta de vontade política demonstrada por diversos países-chave e oposição à liberalização regional por parte de setores econômicos que buscavam a manutenção do monopólio sobre seus mercados internos. Sendo assim, em 1968, o tratado foi modificado pelo Protocolo de Caracas, que adiava a liberalização completa do comércio para 1980, meta, inclusive, nunca atingida. ${ }^{19}$ É preciso salientar que a numeração das páginas dos artigos da $D E$ citados neste texto segue a ordem de impressão numérica do site e não da revista impressa.

${ }^{20}$ Seguindo essa linha interpretativa, Miguel Teubal escreveu e a $D E$ publicou o artigo Europay Latinoamerica ante la integración econômica. Nele, o autor compara o desenvolvimento de conceitos paralelos de integração econômica adotados na Europa e na América Latina. Apesar de reconhecer que a criação da ALALC foi, em grande parte, influenciada pelo sucesso das medidas de integração adotadas pela Associação Europeia de Livre Comércio (AELC) e pelo Mercado Comum Europeu, conhecido formalmente como Comunidade Econômica Europeia (CEE), afirma que as condições de um e de outro continente, para a integração regional, são muito distintas. Enquanto as da Europa são sólidas, tendo em vista o potencial econômico e a complementaridade qualitativa da produção regional que motivaram as reduções aduaneiras, as da América Latina dependem, primeiramente, da implementação de "mudanças 
'estruturais' básicas para o desenvolvimento econômico latino-americano" (TEUBAL, 1964, p. 21), seguidas de uma coordenação das políticas de desenvolvimento dos países membros que fosse capaz de promover processos de substituição das importações de forma conjunta, evitando a individualidade de cada país, em especial dos países geograficamente menores.

${ }^{21} \mathrm{O}$ Mercosul tem suas origens na aproximação comercial realizada por Brasil e Argentina. Na ocasião, foram assinados diversos acordos de cooperação bilateral que serviram de base para as futuras negociações desse bloco econômico. O primeiro passo para a formação do Mercosul foi dado com a Ata de Iguaçu, de novembro de 1985, assinada pelos presidentes Raul Alfonsín (Argentina) e José Sarney (Brasil), que consistia em uma declaração de intenções de política externa comum. Em julho de 1988, foi assinado o Programa de Integração e Cooperação Econômica BrasilArgentina (PICE), que se baseava num conceito de uma integração gradual e flexível, assentada sobre acordos específicos por setores industriais. Em seu âmago, estava o projeto de ampliação da competitividade internacional das duas economias, através da dilatação da escala dos mercados. Em novembro de 1988, estabeleceu-se a meta de um mercado comum no prazo de dez anos, fixada pelo Tratado de Integração, Cooperação e Desenvolvimento. A estratégia a ser seguida envolveria uma progressiva união aduaneira, com a redução das taxas alfandegárias até a total eliminação dos obstáculos às trocas bilaterais e a formação de uma zona de livre comércio. Posteriormente, passar-se-ia para o mercado comum no qual se contemplava, também, a livre circulação de capitais e mão-de-obra, o que exigiria a coordenação das políticas econômicas internas dos parceiros. Em julho de 1989, os novos governos de Fernando Collor (Brasil) e de Carlos Meném (Argentina) decidiram acelerar o processo de integração, antecipando o estabelecimento do mercado comum bilateral para 31 de dezembro de 1994. Em seguida, entrou em vigor o Acordo de Complementação Econômica (ACE-14), que determinava a redução gradual das tarifas alfandegárias até sua completa extinção. Coerentes com a sua orientação neoliberal, os dois governos abandonaram a ideia de acordos setoriais, vinculados à situação específica dos ramos produtivos de cada país, preferindo forçar a abertura dos mercados e a livre competição entre as empresas envolvidas. Estas mesmas premissas fundamentaram o Tratado de Assunção de março de 1991, que constituiu o Mercosul, ao qual aderiram também Uruguai e Paraguai. Ver site: www.mercosul.gov.br.

\section{Referências}

ALEIXO, José Carlos Brandi. Integração Latino-americana: considerações políticas e históricas sobre suas bases, processo e significado. Brasília: Coordenada Ed. de Brasília, 1970. 
ALTAMIRANO, Carlos. Para un programa de historia intelectualy otros ensayos. Buenos Aires: Siglo XXI Editores Argentina, 2005.

COMITE EDITORIAL. Nuestros primeros veinticinco años. Desarrollo Económico, Revista de Ciencias Sociales, v. 25, Buenos Aires: 1986, p. 483.

DAGUM, Camilo. La integración y el Crecimiento Económico en América Latina. Desarrollo Económico, n. 14-15, vol. 4, jul./dec. 1964.

DARNTON, Robert. O grande massacre de gatos e outros episódios da história cultural francesa. 2. ed. Rio de Janeiro: Graal, 1989.

DELL, Samuel Sydney. Bloques de Comercio y Mercados Comunes. México: Fondo de Cultura Económica, 1981.

FERRER, Aldo. De Cristóbal Colón a Internet: América Latina y la globalización. Buenos Aires: Fondo de Cultura Económica, 1999.

FERRER, Aldo. Hechos y ficciones de la globalización: Argentina y el Mercosur en el sistema internacional. Buenos Aires: Fondo de Cultura Económica, 1997.

FERRER, Aldo. La Economia Argentina. Buenos Aires: Fondo de Cultura Económica, 1987.

FERRER, Aldo. La Economia Argentina - desde sus orígenes hasta principios del siglo XXI. Buenos Aires: Fondo de Cultura Económica, 2004.

FERRER, Aldo. La Economia Argentina - desde sus orígenes hasta principios del siglo XXI. Porto Alegre: editora FUNAG/Campus, 2006.

FERRER, Aldo. La Economia Argentina: las etapas de su desarrollo y problemas actuales. Buenos Aires: Fondo de Cultura Económica, 1963.

FERRER, Aldo. Modernización, Desarrollo Industrial e Integración Latinoamericana. Desarrollo Económico, n. 14-15, vol. 4, p. 195 a 205, jul./dec., 1964.

GRAMSCI, Antonio. Os intelectuais e a organização da cultura. Rio de Janeiro: Civilização Brasileira, 1981.

HALPERIN DONGHI, Tulio. El espejo de la história. Buenos Aires: Sudamericana, 1987.

HALPERIN DONGHI, Tulio. Nueva narrativa y ciencias sociales. In: Elespejo de la história. Buenos Aires: Sudamericana, 1987.

KAPLAN, Marcos. 30 años de história argentina (1925-1975): el laberinto de la frustación. In: CASANOVA, Pablo González (Coord.). América Latina: história de medio siglo. 2. ed. Coleção América del Sur, Tomo 1. México: Siglo XXI, 1979.

LA CAPRA, Dominick e KAPLAN, Steven (Orgs.). Modern European Intellectual History. Ithaca: Cornell University Press, 1982. 
A integração latino-americana no pensamento de Aldo Ferrer...

MOTA, Carlos Guilherme. Ideologia da Cultura Brasileira. 9. ed. São Paulo: Ática, 1994. Cap. 5.

NEIBURG, Federico e PLOTKIN, Mariano (Org.). Intelectuales y expertos. La constitución del conocimiento social en la Argentina. 9. ed. Buenos Aires: Paidós, 2004.

NOVAES, Adauto (org). O silêncio dos Intelectuais. São Paulo: Companhia das Letras, 2006.

PORTNOY, Leopoldo. Los pólos de desarrollo y la integración de América Latina. Desarrollo Económico, n. 14-15, vol. 4, jul./dec. 1964.

PREBISH, Raúl. El desarrollo económico de la América Latina y algunos de sus principales problemas. [S.1.]: Cepal, 1949.

PREBISH, Rául. Perspectivas para la creación del Mercado Común Latinoamericano. In: INTAL. La Integración Latinoamericana Situación y Perspectivas. Buenos Aires: Instituto para la integración de America Latina, 1965, p. 189-217.

REDAÇÃO CARTA MAIOR. Entrevista - Aldo Ferrer. Disponível em: http:/ / www.cartamaior.com.br/templates/materiaMostrar.cfm?materia_id=15395 Acesso em: 25 fev. 2009.

ROSTOW, W. W. Etapas do Desenvolvimento Econômico. 4. ed. Rio de Janeiro: Zahar, 1971.

SAID, Edward. Representações do Intelectual: as Conferências Reith de 1993. São Paulo: Companhia das Letras, 2005.

SIRINELLI, Jean-François. Os intelectuais. In: RÉMOND, René (Dir.). Por uma história política. Rio de Janeiro: Editora da UFRJ, 1996, p. 231-269.

TEUBAL, Miguel. Europa y Latinoamerica ante la integración econômica. Desarrollo Económico, n. 3, vol. 1, oct./dic. 1961.

WHITE, Hiden. Meta-História: A imaginação histórica do século XIX. São Paulo: USP, 1992. 